\title{
The Practices of Halal Foods and Beverages Supply Chain on Marketing Performance: A Conceptual Framework
}

\author{
Inda Sukati \\ Ali Bawaain \\ Department of Marketing and Entrepreneurship \\ College of Commerce and Business Administration \\ Dhofar University \\ Salalah, Sultane of Oman \\ Corresponding Author: indasukatiutmjb@gmail.com
}

\begin{abstract}
Halal foods and beverages supply chains refer to the process of managing halal foods and beverages products, starting from the point of production to the point of consumption involving various parties in the SC networks. The purpose of the supply chain for halal foods and beverages products is to achieve marketing performance that can be measured by Muslim customer satisfaction and ensure that status food products and halal drinks remain intact or not mixed with non-halal products during the SC process from upstream supply chains to downstream.
\end{abstract}

Keyword: Halal food, supply chain, marketing performance

\section{Introduction}

By increasing the number of Muslim population throughout the world and its spread has significantly increased the demand for food and halal products. Many experts have estimated that the future global Muslim population will increase by two billion seven hundred million Muslim population by 2050, its indicate that aboutone billion Muslims population will increase the whole world's population over the next forty years. Current distribution and forecast of Islamic populations in the world. With a population of around nine hundred eighty-six million in 2010 (around $62 \%$ of the world Muslim population), predicted that the Asia Pacific region will be the largest muslim population, and is expected to maintain this status until 2050.

Until now, research in the SCof the product of halal food and beveragesis still limited [29]. The majority of research in the field of halal foods and beverages especially focuses on aspects of marketing (eg, consumer awareness of food halal) the product of food and drink halal and buying behavior of customer Muslim. In addition, halal food and drink product adoption and branding are some popular topics in previous studies[45][26][3][46][21]. Furthermore,product halal also focuses mainly on meat and poultry [9][32][36]. In addition, little effort has been made to examine the linkages between halal foods and beverages supply chains and marketing performance.

In line with the growing number of Muslim customers around the world, the halal food and drink management has been shifted from an organizational-centered perspective that produces these foods and beverages products to the perspective of halal supply chains. The chain of halal food and beverages can be sophisticated and extensive, and the food being consumed by Muslim customers are in line with their awareness of the halal status of the food they consume [9]. As expected by Muslim customers, halal food and beverages must be made with standard quality features that are recognized and adhere to strict requirements to maintain standards and integrity of halal foods and beverages throughout the entire SC activities. Halal foods and beverages supply chains are vulnerable for several reasons that have been identified. First, there is the possibility of cross contamination between the product of halal food and beveragesand non-halal products at someimportant points in the whole process of the SC of halal foods and beverages products. The problem of contamination of product halal and non-halal products is very large because consumer awareness of halal requirements is still in its low in non-Muslim countries [9][41]. Consumers of halal products worry whether the halal status of foods and beverages products can be guaranteed in the entire SCbecause most foods and beverages products are now sourced from various parts of the world, including non-Muslim countries that contribute to the supply of raw materials to produce products and related halal food and drinks. The authenticity of the halal foods and beverages industry was also tainted by several false reports and fraudulent halal certification [33][47]. In addition, there are also several versions of the halal logo that are not known or made halal labels but are not in accordance with the contents printed on packaging labels for processed foods and beverages products [40]. 
This controversy has created confusion and uncertainty among Muslim consumers regarding whether the products offered are truly halal or only logos are written halal but the contents are not halal

\section{Literature review}

\subsection{The Halal Concept}

The term halal comes from Arabic words which mean actions and products that are valid by Islamic law. In addition, halal sayings are also an important concept in Islam which aims to achieve a better quality of life in Islamic societies, because a Muslim's measure of faith must always keep foods and drinks consumed in good condition and halal [47]. In language, the word "halal" comes from the verb "Halla" which means "to be or to be lawful, legitimate, permissible, not prohibited" expanded "to release, cancel, break, loosen, open, release," In the Quran, there are several Letters which explain the halal rules related to foods and which guide Muslims in their daily practices. The letters in this Quran repeat suggestions for Muslims to only eat healthy and halal food. All content or ingredients contained in foods and beverages products must comply with Islamic diet laws.

Halal foods and beverages supply chains are very sensitive to the effects of various types of mixtures because they believe in halal and healthy quality attributes [9], the importance of maintaining halal integrity throughout SC [41] [8], the essence of avoiding doubtful non-halal food [23], lack of halal control of food norms [33] [48], and consumer sensitivity to halal Muslims [46]. Vulnerability to create legitimate supply chains for designing and managing complex supply chains. This vulnerability cannot be reduced through conventional SC models. The conventional model recognizes the importance of efficiency, but it is not enough to consider other aspects such as ethics, sustainability and human values that are very important for the halal foods and beverages supply chain.

\subsection{Halal Food Supply Chain}

The product of foods and beverages manufacture and transaction shownneed to improve regarding to SCnetwork[43]. Currently, the SCof foods and beverages of are increasingly complex, Muslims customer worrying about the really content of food and drinks they use and how the product of food and beverages are producing in manufacture [9]. Globalization in the SCof food and beverages has indicatedfellow Muslim scholars to deal with some problems such as biotechnology, sources of hidden materials, synthetic materials that are harmful to health, innovation in slaughtering animals that are in accordance with Islamic teachings and processing meat that guides Muslim consumers in their choice [19].

Halal foods and beverages supply chains refer to the process of managing halal foods and beverages products, starting from the point of origin or the source of raw material to the point of consumption involving various parties in the SCfrom raw material suppliers to end users. Activities include source search, sorting, warehousing, transportation, product handling, inventory management, procurement, marketing, and order management, all of which must adhere to the general principles of Sharia law which ensures that foods and beverages products are in good condition and halal.

The main objective of halal SC foods and beverages products is to achieve marketing performance that can be measured by the satisfaction of customers mainly Muslim customers and ensure that food status products and halal drinks remain intact or not mixed with non-product products during the SC process from upstream supply chains to downstream [8]. Today's global foods and beverages products SC increase the complexity of the integrity of halal food, and the problem becomes very large when suppliers or sub-suppliers are located in other non-Muslim countries where non-Muslim involvement in SC is unavoidable. and halal drinks become larger non-halal when food and beverages require long-distance travel and involve many points of handling in the supply of foods and beverages products. This problem can be critical if the parties involved in the whole foods and beverages SC process do not fully understand the halal concept and the importance of maintaining halal integrity. Cross contamination will occur if halal food products are placed together with non-halal products which must be strictly placed in halal and non-halal products. This will lead to marketing performance in this case consumer dissatisfaction with halal food and beverages they consume.

There have been several studies that have been conducted before to develop a halal foods and beverages SCframework. First, the study by [42], initiated the first model to address the principles of the halal SCusing focus groups as a method of data collection. This study has been carried out to determine the performance of the halal SCand the principles that must be considered in halal SCmanagement. However, this study mainly investigates halal goods in general and does not focus on certain halal foods and beverages products. In addition, this research only concentrates on the resilience of the model by looking at the relationship between SCresources, business processes and network structures. In addition, this study does not concentrate on investigating the critical dimensions or factors that build a holistic model of the halal foods and beverages supply chain. 
In addition, this study did not see the relationship between the application of food supply chains and halal drinking to marketing performance, whereas marketing performance was significantly influenced by the halal level of products consumed especially for Muslim consumers. whatever, some elements of this research can be considered in developing a halal food SCpractice model that considers the linkages between the product of halal food and beveragesand their marketing performance.

The second study of the halal SCwas carried out by [35]. This study emphasizes the identification of factors that lead to an effective halal supply chain, focusing only on the poultry industry. This research is a form of qualitative research because data is collected through in-depth interviews with related parties. The conceptual framework proposed and developed, which consists of three factors (halal fodder, appropriate slaughter, and proper separation) that lead to effective halal supply chains. The study found that studies only concentrate on the SCof the poultry industry, where SCprocesses may differ from other types of halal food, because poultry is only the wrong ingredient for producing food, especially processed foods and beverages. In addition, this study also did not investigate the impact of the model on broader marketing and organizational performance. The relevant elements of this study are also considered as part of the variables for developing a model of halal foods and beverages SCpractices to consider the possibility of a link between the SCpractice practices and halal drinks on the marketing performance of the company

Another study, namely the third study on halal supply chains, was carried out by [49], who investigated the factors and problems affecting the development of halal meat SCoperations in the Australian market. This exploratory study applies semi-structured interviews as a method of data collection. Obviously, this study only focuses on the meat SCand not specifically other types of halal food. Similar to the research above, the SCprocess may be different for other halal food categories. Based on the findings of this study, ten factors were found to affect the operation of Australia's halal meat supply chain. This study also did not examine the relationship to marketing performance. However, the relevant factors of this study can be applied in this paper for the purpose of knowing the relationship between the SCpractices of the product of halal food and beveragesand marketing performance.

Although there have been several studies on food supply chains and halal products that have been carried out before, research that addresses the linkages between SCpractices of the product of halal foods and beveragesand marketing performance in particular has not been discussed comprehensively even though there are several studies that seek customer satisfaction. Most of the studies mentioned above focus on the halal SCin general. Thus, the field of food SCmanagement and halal administration still needs further investigation, especially for quantitative research that applies strict statistical methods in the context of processed foods and beverages.

At present, the majority of Muslim consumers are still lacking in skills and time to monitor how SCactivities are handled, and they also cannot check whether cross contamination has occurred [9]. Although halal standards were introduced to regulate production, preparation, handling and storage to a certain extent, they could not confirm that a halal product was consumed. Thus, a truly comprehensive and well-managed SCmanagement approach needs to be developed and adopted to ensure global availability of halal food products so that this model can be linked to the relationship between SCmanagement practices for the product of halal foods and beveragesand their marketing performance.

\subsection{Dimension of Halal food SCPractices}

From systematic publications reviewed on the definition of halal foods and beverages products, halal food management and general food chains, eleven dimensions were identified to determine the model of halal foods and beverages SCpractices. This dimension consists of the physical separation of products, training and personnel, product storage and transportation, ethical practices, product packaging and labeling, product material handling, innovative capabilities, product cleanliness, product safety, Islamic diet law, and availability of resources [44].

\subsection{Halal Food Marketing}

Many literature studies have been carried out on the product of halal food and beveragesthat discuss how to build awareness of the consumer community related to perceptions of halal products, especially foods and beverages products consumed daily and highlight the buying behavior of Muslim and non-Muslim consumers. Researching how Muslim consumers decide to buy the product of halal food and beveragesand analyze the attitudes of Muslim consumers in relation to halal food and beverages has become an interesting topic to study among researchers in the study of halal products and foods [2][22][31][45]. Many other studies have also investigated the attitudes of nonMuslim consumers in relation to the product of halal food and beveragesand the extent to which consumers understand the halal principles that are applied in the market compared to what should have happened [39][14]. 
Research in the field of marketing involves a lot of problems about marketing which are currently being discussed, such as positioning problems, namely how to place products and services offered in the customer's mind, branding problems, namely how companies can build strong branding so that strong branding will improve performance marketing, also the problem of product packaging that is important for protecting products from wet, damaged and so on and labeling problems that must be consistent with what is labeled with the contents in the packaging. all of these problems have emerged as one of the important topics for research in the SCof halal food and beverages.

Placing products in the minds of consumers, known as positioning in marketing terms, is an important marketing strategy that must be applied when these products and drinks are new products in competitive markets. Therefore, determining the right attributes for the product of halal foods and beverageswill affect the success of the placement of new products on the market, in this case the product of halal foods and beverages[15]. In addition, other researcher[1] investigated the detailed problem of everything related to the packaging of halal products. They found that the product packaging and labeling process must also be considered to create authentic and healthy halal foods and beverages products. The same applies to the branding of halal foods and beverages products, where identifying various types that can influence the attitudes and awareness of customers, especially Muslim customers towards halal brands, especially regarding foods and beverages products has been discussed comprehensively in previous literature [24]46][34].

\subsection{Marketing performance}

Marketing performance measurement is part of measuring performance (business), a field that aims to support the implementation of strategies, especially marketing strategies by creating insight into the performance of the product of halal food and beveragescompanies. Although performance measurement is often associated with employee evaluation, it is actually a broader, multidisciplinary and cross-functional discipline that covers all areas and layers of the organization [30][18]. Performance measurement can be described as "a series of organizational processes and applications designed to optimize the implementation of business strategies, while measurement of marketing performance is a process to assess the company's ability in the field of marketing applied by the company.

[18] and is part of the organizational planning process. This planning process ideally consists of four steps: (1) plan, (2) do, (3) check, and (4) action [16]. Business performance measurement focuses on step three, to observe the quality of strategy implementation and to identify areas for improvement. Organizational processes and applications used to determine performance include various activities, such as data collection and analysis, performance appraisal, and design interventions to improve marketing performance.

Marketing performance is an important activity for customer-oriented company. Marketing performance measurement aims to assess "the relationship between marketing activities and business performance or marketing performance [12]. Marketing deals with all activities carried out to stimulate, facilitate, and accelerate sales [28][4]. Effective marketing practices generate success by winning and maintaining customer preferences, which support the achievement of longterm goals [5]. In this process marketing should not be understood as a separate function in the company, but as a shared responsibility of the whole business [17][20]. Marketing performance measurement focuses on valuation (1) how well customer preferences are won and maintained, (2) the extent to which contributes to stimulation, facilitation, and sales acceleration, and (3) how it affects the company's overall performance Marketing performance can in this process contribute to the following four functions: (1) annual plan control, (2) profitability control, (3) efficiency control, and (4) strategic control. The first and last functions differ from each other in the sense that annual plan controls attempt to evaluate if the planned results are realized, while strategic control seeks to assess whether the best market, product, and channel opportunities are pursued [25].

In many of the past decades the measurement of marketing performance has been strongly influenced by several new marketing perspectives and paradigms [11]. Especially the change from transactional marketing that focuses on maximizing the number of one-time transactions to marketing relationships that are cantered around developing longterm relationships with profitable customers has been influential in measuring marketing performance [12-13][37]. Under the customer transaction perspective, it is considered a passive target while marketing is seen as a cost centre[27]. The measurement of marketing performance under this perspective focuses on the number and quality of one-time sales and transactions. Conversely, measuring marketing performance in a relational view concentrates on evaluating the quality and value of long-term relationships with customers and other parties [37][10].. The central element of this paradigm is management of customer expectations, both in the pre-sales and after-sales processes [11]. Both perspectives are not mutually exclusive and can safely coexist in a company [38].

In relational marketing three flows can be distinguished, becoming (1) marketing services, (2) relationship management and (3) the perspective of industrial marketing and purchasing. When service marketing emphasizes the role of services in improving customer relationship quality and increasing loyalty, the relationship management view concentrates on consumer interaction, dialogue, and perceived value [37][10]. 
To make use of efforts in interaction and dialogue, companies must concentrate on attracting customers whose loyalty can be won and maintained. Last but not least, marketing and purchasing industry is filled with business-to-business relationships and business networks. This marketing approach also takes into account the purchasing side of a company, as well as the relationship with network suppliers, free products and services [37][10].

However, to measure marketing performance, many researchers have conducted research on measuring marketing performance, [44] investigated the relationship between halal foods supply chains and organizational performance. He divides organizational performance into two, namely financial performance and marketing performance. He made measurements for marketing performance including (1) market share (2) market coverage (3) brand image (4) improving product quality [44]. However, this research more focus on the following measurement (1)) customer satisfaction, (2) market share, (3) customer retention or loyalty, (4) handling customer's complaint/enquiries, (5) competitive position and (6) Ability stay in the business.

\subsection{Research Model and Research Hypotheses}

The proposed research model consists of 17 key constructs, including 11 independent variables, and 6 dependent variables (see Figure 2.1). The independent variables are (1) cleanliness, (2) safety, (3) Islamic dietary law, (4) physical segregation, (5) material handling, (6) Storage and transport, (7) Packaging and labeling, (8) ethical practices, (9) training and personal, (10) innovative capability, and (11) resource availability. The dependent variables consist of (1) customer satisfaction, (2) market share, (3) customer retention/loyalty, (4) handling customer's complaint/enquiries, (5) competitive position and (6) ability stay in the business.

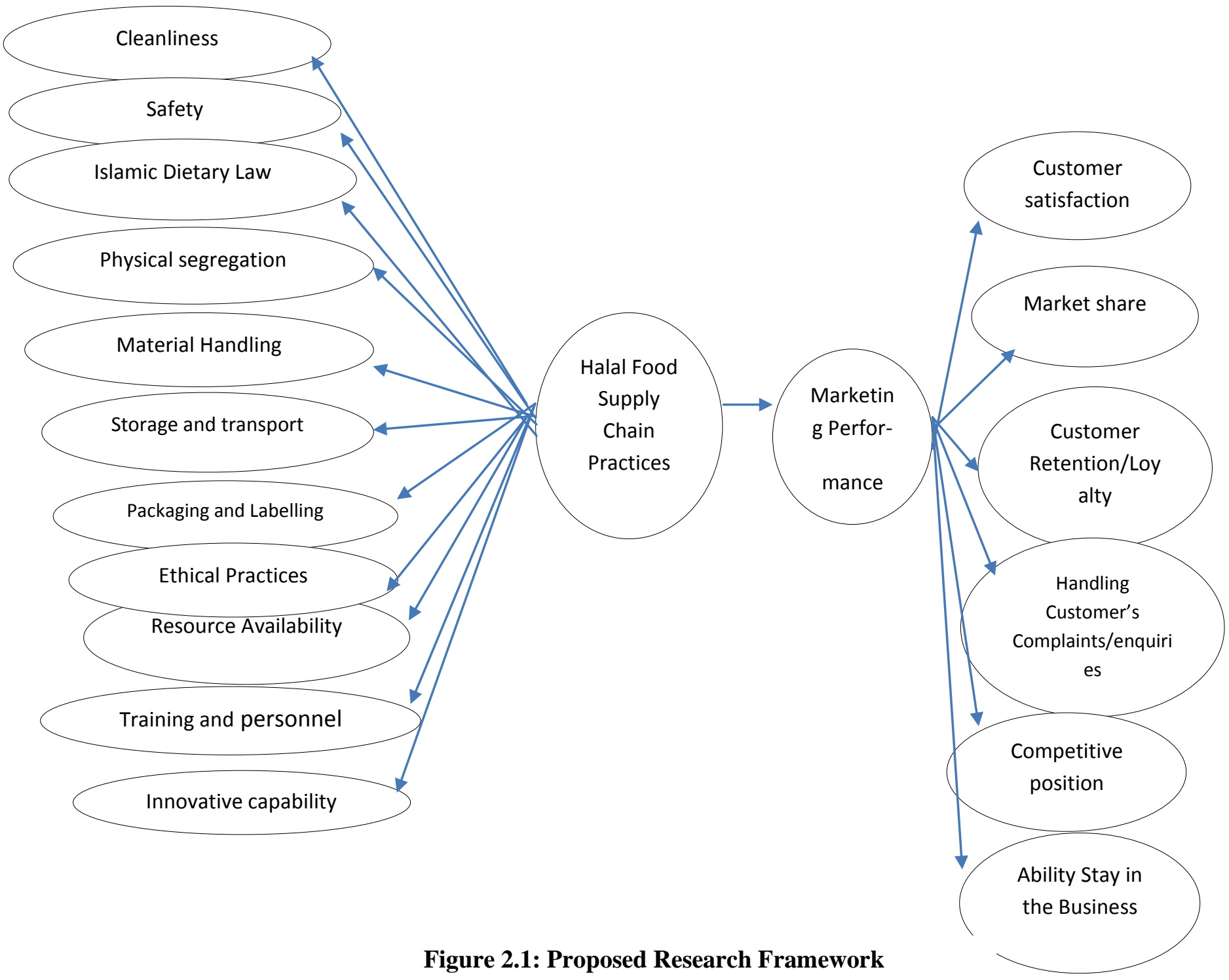


Based on the proposed model of halal food SCas having the dimensions of cleanliness, safety, Islamic dietary law, physical segregation, material handlings, storage and transport, packaging and labelling, ethical practices, training and personnel, resource availability and innovative capability, and marketing performance the following hypotheses is proposed:

$\mathrm{H}_{1 \mathrm{a}}-\mathrm{H}_{1 \mathrm{k}}$ : Marketing performance is positively related to (1) product cleanliness, (2) product safety, (3) Islamic dietary law, (4) product physical segregation, (5) product material handling, (6) product storage and transport, (7) product packaging and labeling, (8) ethical practices, (9) training and personal, (10) innovative capability, and (11) resource availability

$\mathrm{H}_{2 \mathrm{a}}-\mathrm{H}_{2 \mathrm{k}}$ : customer satisfaction is positively related to (1) product cleanliness, (2) product safety, (3) Islamic dietary law, (4) product physical segregation, (5) product material handling, (6) product storage and transport, (7) product packaging and labeling, (8) ethical practices, (9) training and personal, (10) innovative capability, and (11) resource availability

$\mathrm{H}_{3 \mathrm{a}}-\mathrm{H}_{3 \mathrm{k}}$ : Market share is positively related to (1) product cleanliness, (2) product safety, (3) Islamic dietary law, (4) product physical segregation, (5) product material handling, (6) product storage and transport, (7) product packaging and labeling, (8) ethical practices, (9) training and personal, (10) innovative capability, and (11) resource availability

$\mathrm{H}_{4 \mathrm{a}}-\mathrm{H}_{4 \mathrm{k}}$ : Customer retention/loyalty is positively related to (1) product cleanliness, (2) product safety, (3) Islamic dietary law, (4) product physical segregation, (5) product material handling, (6) product storage and transport, (7) product packaging and labeling, (8) ethical practices, (9) training and personal, (10) innovative capability, and (11) resource availability

$\mathrm{H}_{5 \mathrm{a}}-\mathrm{H}_{5 \mathrm{k}}$ : Handling customer's compliant is positively related to (1) product cleanliness, (2) product safety, (3) Islamic dietary law, (4) product physical segregation, (5) product material handling, (6) product storage and transport, (7) product packaging and labeling, (8) ethical practices, (9) training and personal, (10) innovative capability, and (11) resource availability

$\mathrm{H}_{6 \mathrm{a}}-\mathrm{H}_{6 \mathrm{k}}$ : Competitive position is positively related to (1) product cleanliness, (2) product safety, (3) Islamic dietary law, (4) product physical segregation, (5) product material handling, (6) product storage and transport, (7) product packaging and labeling, (8) ethical practices, (9) training and personal, (10) innovative capability, and (11) resource availability

H7a-H7k: Ability to stay in business is positively related to (1) product cleanliness, (2) product safety, (3) Islamic dietary law, (4) product physical segregation, (5) product material handling, (6) product storage and transport, (7) product packaging and labeling, (8) ethical practices, (9) training and personal, (10) innovative capability, and (11) resource availability

\section{References:}

Ab Talib, MS \& Mohd Johan, MR 2012, 'Issues in Halal Packaging: A Conceptual Paper', International Business and Management, vol. 5, no. 2, pp. 91-5.

Abdul, M, Ismail, H, Hashim, H \& Johari, J 2009, 'Consumer decision making process in shopping for halal food in Malaysia', China-USA Business Review, vol. 8, no. 9, pp. 40-47.

Alam, SS \& Sayuti, NM 2011, 'Applying the Theory of Planned Behavior (TPB) in halal food purchasing', International Journal of Commerce and Management, vol. 21, no. 1, pp. 8-20.

Alsem, K.J. (2007). Strategic marketing: an applied perspective. New York: McGraw-Hill.

Ambler, T. \& Kokkinaki, F. (2002). Measuring marketing performance: which way is up? In: A.D. Neely (ed.), Business performance measurement: theory and practice (pp. 225-243). Cambridge: Cambridge university press.

Ali, MH, Tan, KH, Pawar, K \& Makhbul, ZM 2014, 'Extenuating Food Integrity Risk through Supply Chain Integration: The Case of Halal Food', Industrial Engineering \& Management Systems, vol. 13, no. 2, pp. 15462.

Al-Jallad, N 2008, 'The concepts of al-halal and al-haram in the Arab-Muslim culture: a translational and lexicographical study', Language Design: Journal of Theoretical and Experimental Linguistics, vol. 10, pp. 7786.

Bahrudin, SSM, Illyas, MI \& Desa, MI 2011, 'Tracking and tracing technology for Halal product integrity over the supply chain', paper presented to 2011 International Conference on Electrical Engineering and Infromatics, Bandung, Indonesia, 17-19 July, 2011. 
Bonne, K \& Verbeke, W 2008, 'Religious values informing halal meat production and the control and delivery of halal credence quality', Agriculture and Human Values, vol. 25, no. 1, pp. 35-47.

Bush, R.P., Underwood, J.H., Sherrell, D.L. (2007). Examining the relationship marketing, marketing productivity paradigm: establishing an agenda for current and future research. Journal of Relationship Marketing, 6(2), pp. 9-32.

Blythe, J. (2006). Principles \& practice of marketing. London: Thomson learning.

Clark, B.H. \& Ambler, T. (2001). Marketing performance measurement: evolution of research and practice. International Journal of Business Performance Measurement, 3(2/3/4), pp. 231-244

Clark, B. (2002). Measuring performance: the marketing perspective. In: Neely, A.D. (ed.), Business performance measurement: theory and practice (pp. 22-36). Cambridge: Cambridge university press.

Danesh, MMS, Chavosh, A \& Nahavandi, M 2010, 'Comparative analysis of the Muslims' and non-Muslims' satisfaction with Halal products', paper presented to Advanced Management Science (ICAMS), 2010 IEEE International Conference on.

Cosmetics Product That Influence Its Positioning Strategy in Malaysian Market', Journal of Applied Sciences Research, vol. 8 , no. 1.

Deming, W.E. (1982). Out of the crisis. Cambridge: Massachusetts Institute of Technology

Drucker, P.F. (1954). The practice of management. New York: Harper \& Row.

Eckerson, W.W. (2006). Performance dashboards. Measuring, monitoring, and managing your business. New Jersey: John Wiley and Sons

Fischer, J 2011, 'The halal frontier', in The Halal Frontier, Springer, pp. 1-30.

Grönroos, C. (2007). Service management and marketing. Customer management in service competition (third edition). West Sussex: John Wiley \& Sons.

Hanzaee, KH \& Ramezani, MR 2011, 'Intention to Halal Products in The World Markets', Interdisciplinary Journal of Research in Business, vol. 1, no. 5, pp. 01-07.

Ireland, J \& Rajabzadeh, SA 2011, 'UAE consumer concerns about Halal products', Journal of Islamic Marketing, vol. 2, no. 3, pp. 274-83.

Kamali, MH 2010, 'The Halal industry from a shari'ah perspective', Islam and Civilisational Renewal, vol.1, no. 4.

Kordnaeij, A, Askaripoor, H \& Bakhshizadeh, A 2013, 'Studying affecting factors on customers' attitude toward products with Halal brand (case study: Kuala Lumpur, Malaysia)', International Research Journal of Applied and Basic Sciences, vol. 4, no. 10, pp. 3138-45.

Kotler, P. \& Keller, K.L. (2006). Marketing management (twelfth edition). Upper Saddle River: Pearson Prentice-Hall.

Lada, S, Tanakinjal, GH \& Amin, H 2009, 'Predicting intention to choose Halal products using theory of reasoned action', International Journal of Islamic and Middle Eastern Finance and Management, vol. 2, no. 1, pp. 66-76.

Lamberti, L. \& Noci, G. (2010). Marketing strategy and marketing performance measurement system: exploring the relationship. European Management Journal, 28(2), pp. 139-152.

Lee, J., Hock, R., Podlaseck, M., Schonberg, E. \& Gomory, S. (2000a). Analysis and visualization of metrics for online merchandising. Lecture Notes in Computer Science, 1836(1), pp. 126-141.

Lodhi, A-u-H 2009, Understanding Halal Food Supply Chain, HFRC UK Ltd, London.

Marr, B. \& Schiuma, G. (2003). Business performance measurement - past, present and future. Management Decision, 41(8), pp. 680-687.

Mukhtar, A \& Butt, MM 2012, 'Intention to choose Halal products: the role of religiosity', Journal of Islamic Marketing, vol. 3, no. 2, pp. 108-20.

Nakyinsige, K, Man, YC \& Sazili, AQ 2012, 'Halal authenticity issues in meat and meat products', Meat Sci, vol. 91, no. 3, pp. 207-14.

Norman, AA, Md Nasir, MHN \& Azmi, M 2008, 'The users perceptions and opportunities in Malaysia in introducing RFID system for Halal food tracking', Wseas Transactions On Information Science \& Applications, vol. 5, no. 5.

Nooh, M, Nawai, N, Dali, N, Mohammad, H \& Nilai, BB 2007, 'Halal branding: An exploratory research among consumers in Malaysia', paper presented to 3rd UNITEN International Business Management Conference Human Capital Optimization Strategies Challenges and Sustainability, Malaysia.

Omar, EN \& Jaafar, HS 2011, 'Halal supply chain in the food industry-A conceptual model', paper presented to Business, Engineering and Industrial Applications (ISBEIA), 2011 IEEE Symposium.

Omar, EN, Jaafar, HS, Osman, MR \& Faisol N 2013, ' Halalan toyyiban supply chain management the new insights in sustainable supply chain management', paper presented to ICLT Kyoto, Japan.

Palmer, R., Lindgreen, A. \& Vanhamme, J. (2005). Relationship marketing: schools of thought and future research directions. Marketing Intelligence \& Planning, 23(3), pp. 313-330. 
Pels, J. \& Saren, M. (2005). The 4P"es of relational marketing, perspectives, perceptions, paradoxes, and paradigms: Learnings from organizational theory and the strategy literature. Journal of Relationship Marketing, 4(3/4), pp. 59-84.

Rezai, G, Mohamed, Z \& Shamsudin, MN, 2011, 'Assessment of consumers' confidence on Halal labelled manufactured food in Malaysia', Pertanika Journal of Social Science and Humanities, vol. 19, no. 2, pp. 33-42.

9Talib, A, Ali, KAM \& Jamaludin, KR 2008, 'Quality assurance in halal food manufacturing in Malaysia: A preliminary study', paper presented to International Conference on Mechanical \& Manufacturing Engineering (ICME2008), Johor Bahru, Malaysia.

Tieman, M 2011, 'The Application of Halal in Supply Chain Management : in-depth interviews', Journal of Islamic Marketing, vol. 2, no.2, pp. 186-195.

Tieman, M, van der Vorst, JG \& Che Ghazali, M 2012, 'Principles in halal supply chain management', Journal of Islamic Marketing, vol. 3, no. 3, pp. 217-43.

Tieman, M 2015, 'Halal clusters', Journal of Islamic Marketing, vol. 6, no.1, pp. 2-21.

Wan Omar, WM, Muhammad, 2017, Developing a model for halal food supply chain implementation, PhD Thesis, School of business IT and logistic, college of business, RMIT University.

Wan Omar, WM, Muhammad, MZ \& Omar, CA 2008, 'An analysis of the Muslim consumers' attitudes towards halal food products in Kelantan', paper presented to ECER Regional Conference, UiTM Kelantan, Malaysia, 15 - 17 December 2008.

Wilson, JAJ \& Liu, J 2010, 'Shaping the halal into a brand?', Journal of Islamic

Zailani, S, Arrifin, Z, Abd Wahid, N, Othman, R \& Fernando, Y 2010, 'Halal traceability and halal tracking systems in strengthening halal food supply chainfor food industry in Malaysia (A Review)', Journal of Food Technology, vol. 8, no. 3 .

Zakaria, Z 2008, 'Tapping into the world Halal market: Some discussions on Malaysia laws and standards', Shariah Journal, vol. 16, no. Special edition, pp. 603-16.

Zulfakar, M, Chan, C \& Jie, F 2014, 'Factors influencing the operations of Halal meat supply chain in Australia', paper presented to ISL2014: Designing Responsible and Innovative Global Supply Chains, Ho Chi Minh City, Vietnam. 